\title{
Application of Prestressed Concrete Composite Box-girder Bridges with Corrugated Steel Webs
}

\author{
Ming $\mathrm{Li}^{\mathrm{a}^{*}}$, Jianyong Song ${ }^{\mathrm{b}}$ and Huaijian $\mathrm{Li}^{\mathrm{c}}$ \\ Research Institute of Highway Ministry of Transport, Beijing, China \\ aming.li@rioh.cn, bjy.song@rioh.cn, chuaijian.li@rioh.cn
}

\begin{abstract}
Keywords: bridge engineering; economic efficiency; corrugated steel webs; composite bridges Abstract. Prestressed concrete composite box-girder bridges with corrugated steel webs were introduced in China in the early 21 st century. Now the number of this type of bridges under construction and completed has been more than forty, and China has become the second country where this type of bridges is most widely applied in bridge engineering in the world.

This paper presents the efforts made to promote the application of one of the environment-friendly bridge structures, namely prestressed concrete composite box-girder bridges with corrugated steel webs in China to reduce the concrete consumption. The development characteristics and problems on which further studies would be needed with respect to this type of bridge structure in China are discussed.
\end{abstract}

\section{Introduction}

According to 2003 statistics, the concrete consumption of China has amounted to 2.4 billion cubic meters, accounting for $40 \% \sim 60 \%$ of concrete consumption of the world. The acquisition of huge amounts of sand, stone and cement is at the cost of the ecological environment destruction. So it is a pressing task to propel the application of advantageous bridge structures to reduce the concrete consumption. Propelling the applications of steel structure and composite structure is effective measures of energy saving and discharge reduction. China has kept the first place in reference to the steel output in the world in recent years, which provides condition for the large scale application of the steel and composite structure. Composite bridges have found increased applications in bridge construction in Europe and America. According to statistics, the ratio of composite bridges is $85 \%$ in various bridge structures in France, it is 50\% and 30\% in Japan and America respectively, but it is less than $1 \%$ in China. Prestressed concrete composite box-girder bridge with corrugated steel webs is a new type of composite bridge structure, which includes corrugated steel webs, internal and external prestressed cables and shear connectors that connect the corrugated steel webs and the concrete flange slabs. According to estimation, this type of structure can reduce the concrete volume of bridge superstructure up to $20 \%$.

This kind of bridge originated from France, and it was applied in Japan from the beginning of 90's. Through the construction of the Second Nagoya to Kobe expressway, it has become the predominant bridge type of expressway bridges in Japan; the total of this kind of bridge has exceeded 200. In the early 21 st century, this type of bridges became accepted in China, and the first bridge of this type-Po River Bridge was completed in 2006 in Henan Province. It is the completion of the Juancheng Yellow River Highway Bridge, total span of which broke the span record of this type of bridges in Japan and the establishment of two factories in China which mainly produce corrugated steel webs that advance the development of this type of bridges in China. Now the number of this type of bridges under construction and completed has been more than forty, and China has become the second country where this type of bridges is most widely applied in the world [1-4]. It is not difficult to find that Japan choose this kind of bridge as the first choice for the medium and small bridges with the span of $50 \sim 100 \mathrm{~m}$, whereas China puts emphasis on the prefabrication and assembly construction of this kind of bridge with the span of $40 \mathrm{~m}$ or so as well as the scheme on choosing this kind of bridge to replace the conventional prestressed concrete (abbr. as PC) bridges in the field of large span bridge with the span 
of $150 \sim 200 \mathrm{~m}$. Development characteristics and relevant problems on which further investigation would be needed are presented below.

\section{Construction of large span prestress concrete composite box-girder bridges with corrugated steel webs}

The comparison of large span PC bridges with corrugated steel webs between China and Japan is shown in Table 1. It is known that China began to study this kind of bridge about 10 years later than Japan, but China catches up with a high speed in respect of span. The inducing factors include the large scale bridge construction as well as carving for performance improvement on the PC continuous or rigid frame bridge with the span of $100 \sim 200 \mathrm{~m}$. There are large quantities of bridges in China, and the engineering circles are accustomed to choose conventional PC bridges in the span ranges of 100 $200 \mathrm{~m}$ which are damaged by two bridge diseases which are web cracking and continuous increase in the mid-span deflection. Due to relative light deadweight and small dead load bending moment of PC composite box-girder bridges with corrugated steel webs, there are no cracking diseases in the steel webs [5-7]. Based on the development course of conventional PC bridges, PC composite box-girder bridges with corrugated steel webs will have a bright future.

Table 1. Comparison of large span PC bridges with corrugated steel webs between China and Japan

\begin{tabular}{|c|c|c|c|c|c|}
\hline Bridge name & $\begin{array}{l}\text { Construction } \\
\text { method }\end{array}$ & Bridge type & $\begin{array}{c}\text { Bridge } \\
\text { length }(\mathrm{m})\end{array}$ & Span arrangement(m) & Remarks \\
\hline $\begin{array}{l}\text { Shizuochuan } \\
\text { Bridge(Japan) }\end{array}$ & $\begin{array}{l}\text { Cantilever } \\
\text { construction }\end{array}$ & $\begin{array}{c}4 \text { span PC } \\
\text { cable-stayed bridge }\end{array}$ & 820 & $173.4+2 \times 235+173.4$ & $\begin{array}{c}\text { Largest } \\
\text { cable-stayed bridge }\end{array}$ \\
\hline $\begin{array}{l}\text { Poyang Lake } \\
\text { Bridge(China) }\end{array}$ & $\begin{array}{l}\text { Cantilever } \\
\text { construction }\end{array}$ & $\begin{array}{c}\text { 4span PC } \\
\text { extradosed } \\
\text { cable-stayed bridge }\end{array}$ & 690 & $125+2 \times 220+125$ & \\
\hline $\begin{array}{c}\text { Bachuan } \\
\text { Bridge(Japan) }\end{array}$ & $\begin{array}{l}\text { Cantilever } \\
\text { construction }\end{array}$ & $\begin{array}{c}5 \text { span PC } \\
\text { continuous beam }\end{array}$ & 640 & $\begin{array}{c}84.9+155+164+152 \\
+81.9\end{array}$ & $\begin{array}{l}\text { Largest continuous } \\
\text { bridge }\end{array}$ \\
\hline $\begin{array}{l}\text { Qianshan River } \\
\text { Bridge(China) }\end{array}$ & $\begin{array}{l}\text { Cantilever } \\
\text { construction }\end{array}$ & $\begin{array}{c}3 \text { span continuous } \\
\text { beam }\end{array}$ & 340 & $90+160+90$ & \\
\hline $\begin{array}{c}\text { Rijianmeng } \\
\text { Bridge(Japan) }\end{array}$ & $\begin{array}{l}\text { Cantilever } \\
\text { construction }\end{array}$ & $\begin{array}{l}3 \text { span extradosed } \\
\text { cable-stayed bridge }\end{array}$ & 365 & $91.8+180+91.8$ & $\begin{array}{c}\text { Largest extradosed } \\
\text { cable-stayed bridge } \\
\text { in Japan }\end{array}$ \\
\hline $\begin{array}{l}\text { Chaoyanggou } \\
\text { Bridge(China) }\end{array}$ & $\begin{array}{l}\text { Launching } \\
\text { construction }\end{array}$ & $\begin{array}{l}4 \text { span extradosed } \\
\text { cable-stayed bridge }\end{array}$ & 472 & $58+118+188+108$ & $\begin{array}{l}\text { Largest extradosed } \\
\text { cable-stayed bridge } \\
\text { in China }\end{array}$ \\
\hline $\begin{array}{l}\text { Gongjia Island } \\
\text { Bridge(Japan) }\end{array}$ & $\begin{array}{l}\text { Cantilever } \\
\text { construction }\end{array}$ & $\begin{array}{c}23 \text { span PC } \\
\text { continuous beam }\end{array}$ & 1432 & $\begin{array}{c}51.2+7 \times 53.0+54.0 \\
+85.0+53.0+3 \times 52.0 \\
+58.5+60.0+101.5\end{array}$ & \\
\hline $\begin{array}{l}\text { Chaoyang Gan } \\
\text { River } \\
\text { Bridge(China) }\end{array}$ & $\begin{array}{l}\text { Cantilever } \\
\text { construction }\end{array}$ & $\begin{array}{l}\text { PC continuou beam } \\
\text { and PC cable-stayed } \\
\text { bridge }\end{array}$ & 1610 & $79+5 \times 150+79$ & \\
\hline
\end{tabular}

The beam height of root part of large span PC composite box-girder bridges with corrugated steel webs is inevitable big, based on the design regulations of China and Japan on the PC composite box-girder bridges with corrugated steel webs, inner lining is set to realize gentle transition of shear stress and ensure buckling stability of corrugated steel webs. At the early stage, it is assumed that the shear strength of inner lining concrete can be ignored in the calculation of sheer buckling of corrugated steel webs at the place of pier top for safety consideration. But in the design process of concrete lining, it is suggested that reinforcement calculation is performed based on shear of lining distributed according to the convert area ratio of steel webs to concrete lining. For the large span PC composite box-girder bridges with corrugated steel webs, because of the relatively high beam height, it seems that it cannot be considered conservatively like that. It is one of the key technology problems for large span 
PC composite box-girder bridges with corrugated steel webs that how the shear force is distributed and transferred between the corrugated steel webs and concrete lining(namely steel-concrete composite webs). Study on the problem is now being performed in the construction of the largest PC composite box-girder bridges with corrugated steel webs in China-Zhuhai Qianshan River Bridge.

According to the construction experience of Zhuhai Humen Auxiliary Shipping Channel Bridge and design idea of Chongqing Shibanpo Bridge, PC composite box-girder bridges with corrugated steel webs with the span of 350 meters or so is hopeful to be constructed in China in the near future.

\section{Improve economic efficiency of prestressed concrete composite box-girder bridges with corrugated steel webs}

There are two reasons why Japan tries to promote the applications of PC composite box-girder bridges with corrugated steel webs, one is high economic efficiency of this kind of bridge, and the other is good earthquake resistance performance. According to the Japanese statistics, compared with the conventional PC bridges, this type of bridge can reduce the concrete volume of bridge superstructure up to $8 \%$ at least. Index of usage amount of main material per square meter bridge deck of several PC composite box-girder bridges with corrugated steel webs in China is listed in the Table 2, the number behind the symbol" $/$ " is the corresponding value derived from the statistics value of one hundred and thirty PC bridges with corrugated steel webs situated in Japan. It is known from Table 2, the economic efficiency of PC bridges with corrugated steel webs in China is equivalent with those in Japan or slightly more economical than those in Japan.

Table 2. Comparison of usage amount of main material of PC composite box-girder bridges with corrugated steel webs between China and Japan

\begin{tabular}{|c|c|c|c|c|c|}
\hline Bridge name & $\begin{array}{c}\text { Span } \\
\text { arrangement } \\
\text { bridge } \\
\text { width }(\mathrm{m})\end{array}$ & $\begin{array}{c}\text { Concrete/ } \\
\text { statistical } \\
\text { value }\left(\mathrm{m}^{3} / \mathrm{m}^{2}\right)\end{array}$ & $\begin{array}{c}\text { Reinforcement/ } \\
\text { statistical } \\
\text { value }\left(\mathrm{kg} / \mathrm{m}^{2}\right)\end{array}$ & $\begin{array}{c}\text { Steel plate/ } \\
\text { statistical } \\
\text { value }\left(\mathrm{kg} / \mathrm{m}^{2}\right)\end{array}$ & $\begin{array}{c}\text { Prestress } \\
\text { tendon/ } \\
\text { statistical } \\
\text { value }\left(\mathrm{kg} / \mathrm{m}^{2}\right)\end{array}$ \\
\hline $\begin{array}{c}\text { Juancheng } \\
\text { Yellow } \\
\text { River } \\
\text { Bridge }\end{array}$ & $\begin{array}{c}70+11 \times 120+70 \\
2 \times 13.5\end{array}$ & $0.84 / 0.91$ & $137.7 / 182.3$ & $69.1 / 93.5$ & $48.5 / 46.7$ \\
\hline $\begin{array}{c}\text { Shenzhen } \\
\text { Pingtie } \\
\text { Bridge } \\
\end{array}$ & $\begin{array}{c}80+130+80 \\
2 \times 27\end{array}$ & $1.07 / 0.95$ & $151.8 / 193.2$ & $92.6 / 99.4$ & $56.5 / 48.8$ \\
\hline $\begin{array}{c}\text { Taohuayu } \\
\text { Yellow River } \\
\text { Bridge } \\
\end{array}$ & $\begin{array}{c}75+135+75 \\
2 \times 16.25\end{array}$ & $0.93 / 0.96$ & $190.3 / 198.5$ & $83.07 / 102.3$ & $56.67 / 49.9$ \\
\hline $\begin{array}{c}\text { Zhuhai } \\
\text { Qianshan } \\
\text { River Bridge }\end{array}$ & $\begin{array}{c}90+160+90 \\
2 \times 15.75\end{array}$ & $1.083 / 1.059$ & $176.82 / 225.47$ & $100.75 / 116.88$ & $62.0 / 55.37$ \\
\hline $\begin{array}{c}\text { Iran BR-06 } \\
\text { Bridge }\end{array}$ & $\begin{array}{c}83+153+83 \\
2 \times 13.1 \\
\end{array}$ & $0.955 / 1.041$ & $167.99 / 220.1$ & $122.44 / 113.96$ & $56.26 / 54.28$ \\
\hline
\end{tabular}

The comparison of material usage amount of PC composite box-girder bridges with corrugated steel webs with corresponding conventional PC bridges is shown in Table 3 . It is known that due to the application of PC composite box-girder bridges with corrugated steel webs, the Juancheng Yellow River Highway Bridge can save the construction cost up to $22 \%$ 。

The construction of PC composite box-girder bridges with corrugated steel webs is a mature technology, but it is also technology innovation to propel the application of this kind of bridge in China. Economic efficiency is often the first concern for people on innovation. If someone wants to propel the application of this kind of bridge further, attention should be paid to economic efficiency. 
Table 3. Comparison of material usage amount of PC composite box-girder bridges with corrugated steel webs with corresponding conventional PC bridges

\begin{tabular}{|c|c|c|c|c|c|c|}
\hline Component & Material & Unit & $\begin{array}{c}\text { Construction } \\
\text { drawing design } \\
\text { (PC bridge } \\
\text { with corrugated } \\
\text { steel webs) }\end{array}$ & $\begin{array}{l}\text { Initial design } \\
\text { (conventional } \\
\text { PC bridge) }\end{array}$ & $\begin{array}{c}\text { Amount of } \\
\text { saved } \\
\text { materials }\end{array}$ & $\begin{array}{c}\text { Saved } \\
\operatorname{ratio}(\% \\
)\end{array}$ \\
\hline 1 & 2 & 3 & 4 & 5 & 6 & $6 / 5$ \\
\hline \multirow{9}{*}{ Superstructure } & $\mathrm{C} 50$ & $\mathrm{~m}^{3}$ & 29945 & 38120 & 8175 & 21 \\
\hline & $\begin{array}{c}\text { Corrugated steel } \\
\text { webs }\end{array}$ & $\mathrm{t}$ & 2722 & 0 & 2722 & - \\
\hline & Internal tendon & $\mathrm{t}$ & 1419 & 2231 & 812 & 14 \\
\hline & External tendon & $\mathrm{t}$ & 491 & 0 & 491 & - \\
\hline & $\varphi 32 \mathrm{~mm}$ & $\mathrm{t}$ & 0 & 221 & 221 & 100 \\
\hline & Bellows & $\mathrm{m}$ & 123568 & 188184 & 64616 & 34 \\
\hline & Anchorage & 1 & 49372 & 77644 & 28272 & 36 \\
\hline & HRB335 & $\mathrm{t}$ & 4342 & 6476 & 2134 & 33 \\
\hline & R235 & $\mathrm{t}$ & 0 & 192 & 192 & 100 \\
\hline \multirow{4}{*}{ Substructure } & $\mathrm{C} 30$ & $\mathrm{~m}^{3}$ & 19663 & 19976 & 313 & 1.5 \\
\hline & $\mathrm{C} 25$ & $\mathrm{~m}^{3}$ & 43012 & 48572 & 5560 & 11.4 \\
\hline & HRB335 & $\mathrm{t}$ & 2857 & 3583 & 726 & 18 \\
\hline & R235 & $\mathrm{t}$ & 113 & 603 & 490 & 81 \\
\hline
\end{tabular}

\section{Deepen the recognition on the mechanical properties and calculation theory of prestressed concrete composite box-girder bridges with corrugated steel webs}

The basic assumption of PC composite box-girder bridges with corrugated steel webs are as follows:

1) Because of the accordion effect of corrugated steel webs, the bending strength of corrugated steel webs can be ignored and only the bending strength of concrete top and bottom flabs need to be taken into consideration.

2) The flexural plane section assumption is tenable.

3) The shear is all born by the corrugated steel webs, and the shear stress is even distributed in the direction of web height.

Combined with construction of PC composite box-girder bridges with corrugated steel webs, many flexural tests are conducted to demonstrate the above mentioned two assumptions. Meanwhile, the correctness of theoretical assumption is confirmed by the construction monitoring and control of large number of PC composite box-girder bridges with corrugated steel webs during the cantilever casting construction.

When the PC composite box-girder bridges with corrugated steel webs are designed, how to consider the effect of shear deformation on the flexural deflection and checking calculation of shear buckling of corrugated steel webs are two key problems [8-10]. Combined with construction of PC composite box-girder bridges with corrugated steel webs, much research work has been done in China. Research results has been reflected in the local standards of Henan Province "Design Codes for Highway PC Box-girder Bridges with Corrugated Steel Webs"(DB 41/T643-2010), local standards of Guangdong Provence "Design and Construction Regulations of PC composite box-girder bridges with corrugated steel webs". 


\section{Application of shear connector with Chinese characteristics}

Shear connector of angle steel type is always applied in the early composite box-girder bridges with corrugated steel webs. However, perfobond shear connector is mostly used these days. The submerged shear connector is adopted in the Bengu Bridge (with the span arrangement of $40 \mathrm{~m}+97.7 \mathrm{~m}+44 \mathrm{~m}$ ) completed in 1995, both the structure and economical effect are well, but the application of this kind of shear connector decrease thereafter. The submerged shear connector is applied in the record breaking Juancheng Yellow River Highway Bridge situated in Shandong Province of China, the economic benefit is very well, and there is no fatigue problem of welding located in the top and bottom flabs and webs, but the subsequent bridge seldom employ this type of shear connector.

Because there is difficulty in the concrete casting of bottom flab of the PC composite box-girder bridges with corrugated steel webs-Taohuayu Yellow River Bridge situated in Henan Province, the shear connector of angle steel type is adopted finally instead of the original type of S-Perfobond plus studs, and shear connectors tests were conducted. Both tests and theory researches show that the shear connectors of angle steel type have the advantages of stressing definite and reliable, easy to ensure concrete compacting, so shear connector of angle steel type is more and more adopted in real bridges.

Studs connection is the most common type of shear connectors which have the advantages of low cost, easy to construction, applicable to bear multi-directional shear force. The stud connection belongs to elastic connection, so there are misgivings on the combination of the stud connection with corrugated steel webs with accordion effect, which hinders the application of this type of shear connector in the PC composite box-girder bridges with corrugated steel webs. In the design of the extradosed cable-stayed bridge--Zhengzhou Chaoyanggou Reservoir Bridge (with the span arrangement of $58 m+118 m+188 m+108 m)$, the stud connection is adopted in the connection of the corrugated steel webs and PC top and bottom flabs.

The shear connection of corrugated steel webs and PC top and bottom flabs is associated with the design economic efficiency of PC composite box-girder bridges with corrugated steel webs, which needs to choose cautiously. If the joist steel formed by the flange plate and corrugated steel webs is employed to bear load in the design and construction of PC composite box-girder bridges with corrugated steel webs, the shear connector of angle steel type where flange is set is suitable to choose. If the corrugated steel webs are not employed to bear load in in the construction process, the shear connector of submerged type is the most economic choice.

\section{Bring the constructability of PC bridges with corrugated steel webs into full play}

The flange flabs connected with corrugated steel webs can bear load at the stage of construction and installation, which can be used to form the construction method of Rap con/RW. Toudao River Bridge (with span arrangement of $72 \mathrm{~m}+130 \mathrm{~m}+72 \mathrm{~m}$ ) situated in Sichuan Province will be constructed with this method. The corrugated steel webs with flange flabs can be used to be guiding beam in the launching construction. The Changzhuang Main Canal Bridge (with span arrangement of $9 \times 50 \mathrm{~m}+9 \times 50 \mathrm{~m}+40 \mathrm{~m}$ ) is constructed by this method, and the scale has exceeded the Daoqichuan Bridge of Japan. Both Yuwotou Interchange Ramp situated in the City of Guangzhou and Kuandian Bridge located in the City of Fanyang of Liaoning Province realizes construction without supports. China has made marked progress on the exploration of PC bridges with corrugated steel webs.

\section{Conclusions}

With the large increase of steel output of China, it is responsibility to propel the application of steel bridge and steel-concrete composite bridge. Taking the concrete pavement into consideration, to develop the steel-concrete composite bridge is more accord with operation condition for highway and city bridges, generalized steel-concrete composite bridges include PC bridges with corrugated steel webs, steel pipe concrete bridges, steel-concrete composite truss bridges, steel-concrete composite 
girder bridges. Through comparing structural performance, economic efficiency and constructability of various steel-concrete composite bridges, it is known that PC bridges with corrugated steel is superior to other bridge types and more suitable to develop in China, which will make great contribution to reduce the concrete consumption and carbon dioxide emission.

\section{Acknowledgements}

This work was granted financial support by the National Natural Science Foundation of China under Grant No. 51278521.

\section{References}

[1] M. YANG, Y. SUN, S.R. ZHANG and Q. HUANG, Development and Prospect of Externally Prestressed Box Beams with Corrugated Steel Webs, Journal of Highway and Transportation Research and Development, Vol. 23 (2006), p.72-75.(In Chinese)

[2] A.M. YUAN, H. DAI and Y.L. DONG, The Latest Study Development in Composite Bridge with Corrugated Steel Webs, Journal of Qingdao Technological University, Vol. 29 (2008), p.30-35. (In Chinese)

[3] Y. WANG, Research on Composite Bridge Beam of Corrugated Steel Web and Prestressed Concrete, Journal of Water Resources and Architectural Engineering, Vol. 6 (2008), p.61-63. (In Chinese)

[4] J.B. CHEN, S. WAN, W.J. MENG, W.P ZHANG and J.F. JIN, Application and Research of Prestressed Concrete Composite Box -girder with Corrugated Steel Webs, Journal of Heilongjiang Institute of Technology, Vol. 20 (2006), p.18-22. (In Chinese)

[5] B.C. CHEN, Y.Y. CHEN and S. LIN, Investigation and Analysis on the Application of Bridge with Corrugated Steel Webs, Journal of China \& Foreign Highway, Vol. 30 (2010), p.109-118. (In Chinese)

[6] Y. TANG, Application and Study on Prestressed Concrete Composite Box Girder Structure of Corrugated Steel Webs, Journal of North China Institute of Water Conservancy and Hydroelectric Power, Vol. 30 (2009), p.8-12. (In Chinese)

[7] S. WAN, S. LI and L. MA, Application of Prestressed Concrete Composite Box-girder Structure with Corrugated Steel Webs in Bridge Engineering in China, Journal of Architecture and Civil Engineering, Vol. 26 (2009), p.15-19. (In Chinese)

[8] C.S. WANG, J.G. NIE, State of the Art of Fatigue Tests and Fatigue Performance of Composite Girders with Corrugated Steel Webs, Journal of Harbin Institute of Technology, Vol. 37 (2005), p.222-225. (In Chinese)

[9] S.Q. LI, J.B. CHEN, S. WAN and H.L. CHEN, Application of the Prestressed Concrete Box-girder with Corrugated Steel Webs in Bridge Engineering in China, Engineering Mechanics, Vol. 26 (2009), p.115-118. (In Chinese)

[10] L.F. LI, J.Q. HOU, Z.Y. YUAN and B. XU, Exploration of Designing Composite Team with Corrugated Steel Webs, Journal of Highway and Transportation Research and Development, Vol. 31 (2014), p.67-70. (In Chinese) 